\title{
"El espíritu francés" (1898). Presentación y edición de un artículo desconocido de Rubén Darío
}

\author{
Alfonso García Morales ${ }^{1}$
}

Resumen. En julio de 1898 la parisina Revue des Revues publicó una "enquête" realizada a destacados intelectuales franceses sobre si existía una identidad o "espíritu francés" distinguible en su literatura y sobre la posibilidad de que los escritores extranjeros pudieran asimilarlo. Dos meses después Rubén Darío se sumó por su cuenta a la encuesta y respondió en "El espíritu francés", un artículo publicado en el semanario El Sol del Domingo de Buenos Aires y desconocido hasta hoy, en el que reafirmó de manera inequívoca su "galicismo mental", su identificación con la modernidad universal representada por Francia y su derecho de reconocimiento y pertenencia a la República mundial de las letras con centro en París. El texto que aquí se presenta y anota es una pieza más del todavía incompleto rompecabezas textual de Darío, y arroja nueva luz sobre un momento particular de su relación con la "patria intelectual" francesa, asunto central de su discurso crítico y de la construcción de su lugar como escritor.

Palabras clave: Rubén Darío; “El espíritu francés”; El Sol del Domingo; 1898; modernismo; cosmopolitismo; francofilia; "galicismo mental"; "patria intelectual"; latinismo.

\section{[en] ‘El espíritu francés’ (1898). Presentation and Edition of an Unknown Article by Rubén Darío}

\begin{abstract}
In July 1898, the French magazine Revue des Revues published an enquete addressed to prominent French intellectuals around the question of whether or not the so-called French spirit existed in their literature and the possibility that this essence could be somehow assimilated by foreign authors. Two months later, writer Rubén Darío joined on his own account this debate, releasing "El espíritu francés", in the weekly newspaper El Sol del Domingo, published in Buenos Aires. In this article, unknown until this date, the author firmly upheld his Francophilia -what was defined as galicismo mental- or identification with the universal modernity epitomized by France, and his right of belonging to the world literature Republic which had Paris as its capital. The text presented and commented in this paper is another piece of the unfinished textual map embodied by Darío, casting some new light on a particular moment of his relationship with the French "intellectual homeland", a crucial aspect in both his critical discourse and the constitution of his place as a writer.
\end{abstract}

Keywords: Rubén Darío; "El espíritu francés"; El Sol del Domingo; 1898; Modernism; cosmopolitanism; francophilia; galicismo mental; "intellectual homeland"; Latinism.

Sumario. 1. Presentación. Darío, "El espíritu francés” y la ciudadanía literaria universal. 2. Rubén Darío: "El espíritu francés”, El Sol, Buenos Aires, 4 de septiembre de 1898, p.1.

Cómo citar: García Morales, A. (2020) "El espíritu francés” (1898). Presentación y edición de un artículo desconocido de Rubén Darío, en Anales de Literatua Hispanoamericana 49, 91-106.

\section{Presentación. Darío, “El espíritu francés” y la ciudadanía literaria universal}

En marzo de 1898 el periodista y sociólogo Jean Finot, director de La Revue des Revues de París, promovió una encuesta de opinión entre una treintena de reputados hombres de letras de Francia sobre el siempre arduo asunto de la identidad nacional aplicado a la literatura. Era el final de un siglo que, desde sus comienzos románticos, había alentado la creencia en los "espíritus" de los pueblos, un siglo a lo largo del que se habían ido escribiendo las primeras historias literarias nacionales, y durante cuya segunda mitad la sociología había 
surgido como disciplina y la encuesta empezaba a emplearse con más o menos rigor como instrumento de análisis en distintos ámbitos. En su carta-cuestionario Finot empezó señalando las incertidumbres que planteaba "la répétition fréquente de ces mots: esprit français, race française, âme française, instinct français, culture française, etc.", y formuló tres preguntas:

I. La France peut-elle prétendre à un esprit particulier dans les lettres, en un mot à un genre d'esprit français, qui ne serait pas celui des autres peuples?

II. Si oui, y a-t-il des côtés saisissables et définissables de cet esprit et à quoi se réduisent-ils ?

III. Un étranger peut-il, dans ce dernier cas, s'approprier totalement ces particularités purement françaises jusqu'à devenir un savant, un romancier ou un poète purement français ? ("Enquête..." 2).

Por lo que sabemos, Jean Finot seguramente tendría razones personales e ideológicas para hacerse y hacer estas preguntas. Judío nacido en Polonia en 1858, de nombre anterior Jean Finckelhaus, muy pronto se trasladó a París. En 1892 comenzó a dirigir la respetable Revue de Revues, en 1896 fue nombrado Caballero de la Legión de Honor y al año siguiente le fue concedida la nacionalidad francesa, de la que se manifestaba extraordinariamente orgulloso. Cuando el escándalo Dreyfus destapó el antisemitismo arraigado en Francia, inició una campaña que culminaría en su libro Le préjugé des races (1905), uno de los intentos pioneros de desmontar los falsos argumentos científicos con los que el racismo se había rearmado a lo largo del siglo XIX. Atendieron a su consulta sobre el espíritu francés veintisiete "intelectuales", mayoritariamente escritores y críticos, pero también algún sociólogo, historiador, científico y político, y en el número del 1 de julio, previo al día de la fiesta nacional, las respuestas aparecieron reproducidas por orden alfabético ${ }^{2}$. La última era la de Émile Zola, protagonista del momento, tan admirado como odiado por su crucial intervención a favor del capitán Dreyfys en el Affaire que conmocionaba y dividía la sociedad francesa, un asunto de fondo que subyace sin mención directa en la "enquête".

Esta no arrojó resultados importantes ni muy variados. Aparte de un par de encuestados que se excusaron por falta de tiempo o espacio para responder a cuestiones tan complejas, y de otro par que dijeron no creer en absoluto en la realidad de tal "espíritu francés", los restantes afirmaron su existencia, si bien dudaron y divagaron bastante al intentar precisar sus características. La pretendida objetividad de la encuesta chocaba con el halo de misterio, emociones y estereotipos que rodeaba, y aún rodea, al concepto de nación. Finot invitaba a los lectores a sacar por sí mismos conclusiones, pero a continuación de la opinión de Zola no dejó de adosar un largo y conclusivo ensayo titulado "La formation, le présent et l'avenir de l'esprit français". Conviene sintetizarlo para tenerlo como referencia de lo que dirá Darío. Finot empieza enfatizando algo que ya habían señalado bastantes de los encuestados: que el "espíritu francés" no puede basarse en la creencia de una "raza francesa", idea insostenible desde un punto de vista científico y causante de divisiones y odios. Desde sus orígenes Francia no había tenido una raza ni tampoco una lengua ni una literatura "puras", sino que estas estaban hechas de intercambios y mezclas constantes que él considera enriquecedoras. Ahora bien, aunque Finot rechaza el nacionalismo puramente étnico, se adhiere a un fervoroso nacionalismo de carácter más cívico, pero también a lo que hoy nos parece un absoluto e inocente etnocentrismo cultural, una creencia sin fisuras en la superioridad de la cultura francesa sobre cualquier otra. No tiene la menor duda de que Francia es la nación que de forma natural, por la bondad del medio, la mezcla supuestamente armoniosa de sangres y la inclinación de sus gentes hacia las cosas del espíritu, estaba destinada a desarrollar y encarnar los valores morales más universales y humanos: la libertad, la igualdad y la fraternidad. Si bien reconoce que no parece el momento propicio para hablar de la nobleza y generosidad de Francia, cuando se escuchan "les cris de

\footnotetext{
2 "Enquête sur l'esprit français" está precedida de la carta cuestionario de Finot fechada el 30 de marzo de 1898, y seguida de las cartas con que a lo largo de los meses siguientes le fueron respondiendo los que él califica como los escritores "les plus saillants, les plus influents et les plus originaux de la France moderne»: Henry Bérenger, Alfred Binet, Henri de Bornier, Paul Bourget, Michel Bréal, Jules Claretie, François Coppée, Arthur Desjardins, George Fonsegrive, Anatole France, Urbain Gohier, Rémy de Gourmont, Léon Hennique, Alexandre Hepp, Gustave Larroumet, Camille Mauclair, Eugène Müntz, Raymond Poincaré, Marcel Prevost, Edouard Rod, Georges Rodenbach, Francisque Sarcey, Paul Stapfer, SullyPrudhomme, E. M. de Vogüé, René Worms y Émile Zola. Al abordar el significado, los procedimientos y la extensión de la "enquête littéraire” en la prensa francesa durante las décadas de 1890 a 1910, Marie Carbonnel distinguió entre su diversidad de contenidos cinco grandes temas: las condiciones de la profesión literaria, la posición de determinados autores en el campo literario, el estado de los géneros, los balances sobre el pasado, el presente y futuro de la literatura, así como un tipo más amplio, fronterizo e ideológico de asuntos con el que podría relacionarse la encuesta de Finot: "les consultations qui centrent leur propos sur tel aspect saillant de la création contemporaine, analysant par exemple l'influence des littératures étrangères sur la création française et inversement, l'exportation de la littérature nationale en Europe" (Carbonnel 2004: 32 ).
} 
mépris contre les protestants, de mort contre les juifs, et de violence contre les libres penseurs ou les 'intellectuels"' (Finot 1898: 58), estas son manifestaciones en realidad antifrancesas, contrarias al verdadero y tolerante espíritu francés. Literariamente este espíritu no se expresa tanto por la belleza, claridad, precisión o ligereza de estilo, rasgos que -también concede- comparten otras literaturas, sino por la relevancia que los grandes escritores franceses han dado a los principios humanitarios. Y a diferencia de la mayoría de sus encuestados, para quienes era si no imposible sí extremadamente difícil que los escritores extranjeros hicieran completamente suyo el espíritu francés, él cree que este es el más fácil, natural y universalmente asimilable. Francia está llamada, en fin, a ejercer una hegemonía cultural civilizadora y universalmente benéfica; ella se beneficiará de abrir las puertas y acoger a los mejores escritores extranjeros, y estos, especialmente aquellos de países pequeños y marginales, se asimilarán para aprovechar la cultura y las oportunidades que solo Francia les puede brindar. Su discurso no escapa del uso nacional o imperialista francés de "lo universal" (Casanova 2001: 54):

Le sort, en formant la France d'une façon unique dans l'histoire des peuples, lui a imposé le devoir de faire aimer par tous les peuples sa littérature, sa pensée, ses sentiments de liberté, de justice et de fraternité. C'est ainsi que comprirent notre mission et notre "esprit", tous nos grands poètes et grands prosateurs, qui brillent d'une lumière ineffaçable dans notre Panthéon national. C'est à eux que l'esprit français doit d'être devenu le synonyme de compréhension et de générosité ! Là est la source de sa grandeur ; là aussi, la raison de l'admiration et de l'amour qui lui vouent les meilleurs parmi les étrangers (Finot 1898: 59).

El 29 del mismo mes de julio de 1898 el diario La Nación de Buenos Aires publicó la nota sin firma "El espíritu francés", en la que se informaba de la iniciativa de Finot y se reproducían o extractaban algunas de las respuestas. ¿Estaría detrás de ella Rubén Darío? Lo cierto es que este leyó con suma atención la encuesta de Revue des Revues y decidió contestarla por su cuenta en un artículo titulado "El espíritu francés", que apareció algo más de un mes después al frente del primer número de la revista El Sol del Domingo ${ }^{3}$. El hecho de sentirse directamente interpelado, más aún el gesto de intervenir de igual a igual en esta discusión entre intelectuales franceses a la que no se le ha invitado son casi tan significativos como sus propios argumentos y declaraciones.

"El espíritu francés" hay que leerlo sobre el horizonte general de la vida y obra de Rubén Darío, oriundo de un lugar remoto que no figuraba en el mapamundi literario, escritor migrante por necesidad y vocación, artista sincrético de múltiples, cambiantes, adaptativas y muchas veces conflictivas identidades nacionales en el contexto de crisis histórica e ideológica del fin de siglo. "En síntesis, Darío [...] tuvo varias patrias: Nicaragua ('mi patria original'), Chile ('segunda patria mía'), Argentina ('mi patria espiritual'), España ('la Patria madre'), Francia ('la Patria universal') y, en función de su ideario artístico, 'nuestra patria la Belleza"” (Arellano, en Darío 2011: 17; cfr. Salinas 1975: 31-45). Más concretamente "El espíritu francés" pertenece de lleno a la etapa de Darío en que su francofilia estaba muy por encima de cualquier otro sentimiento de pertenencia, en la que él mismo se recordaría como "audaz, cosmopolita", con "una sed de ilusiones infinita" (1967: 627-629). Esto es, al periodo de mayor entusiasmo y decisión de su carrera, a la nutrida serie de actuaciones y publicaciones en que realizó su proyecto de convertirse en el gran representante y líder del movimiento modernista de renovación que -soñaba, casi estaba seguro- habría de llevarlo a él y a los nuevos escritores hispanoamericanos a formar parte de la literatura moderna y universal, cuya máxima expresión era la poesía francesa y cuya capital radicaba en París. Un periodo que, como es sabido, tiene un origen

${ }^{3}$ El presente trabajo puede considerarse una continuación de mi estudio García Morales 2004 y sobre todo de mi recuperación García Morales 2007. En ambos doy noticias sobre El Sol, semanario bonaerense que tuvo varias fases. Apareció el 4 de septiembre de 1898 con el nombre El Sol del Domingo, como publicación crítica y literaria de amplio carácter modernista; desde el número 23 , de 5 de febrero de 1899 , figuró como su director Alberto Ghiraldo, quien en la fecha simbólica del 1 de mayo lo transformó en El Sol. Semanario artístico-literario, de contenido anarquista militante, del que Darío prudentemente terminó desvinculándose. Fue clausurado en julio de 1903, en un clima de represión estatal hacia el anarquismo. Con el objetivo de seguir afinando la bibliografía de Darío, doy la lista íntegra de sus colaboraciones en El Sol del Domingo o El Sol: "El espíritu francés", n 1, 4 septiembre 1898, p. 1; "Libros. El pensamiento de América por Luis Berisso", n 2, 11 septiembre 1898, p. 1; "Mallarmé. Notas para un ensayo futuro", no 3, 18 septiembre 1898, p. 1; "La locura de la guerra", n 4, 25 septiembre 1898, p. 1; "Del amor de París y la influencia de la caña de azúcar, del café y de los cueros en el rastaquerismo", no 7, 16 octubre 1898, p. 1; "Sol del Domingo", n' 11, 13 noviembre 1898, p. 1; "En el álbum de Luis Berisso", n 15, 11 diciembre 1898, p. 1; "José L. Pagano", n 17, 25 diciembre 1898, p. 1; "Helda", $\mathrm{n}^{\circ}$ 21, 22 enero 1899; "Leda", no 23, 5 febrero 1899; "Ofrenda" y "Parsifal", no 34, 1 mayo 1899, pp. 1 y 7; "Israel", n' 36,16 mayo 1899, p. 3; "Un sermón", $\mathrm{n}^{\circ}$ 38, 1 de junio 1899, p. 1; "Marina", n 43, 8 julio 1899, p. 1; "Febea", nº 52, 16 septiembre 1899; "Dezires, layes y canciones", $n^{\circ}$ 71, 16 febrero 1900, p. 3; "Cosas del Cid", no 82, 1 junio 1900, pp. 4-5; "Ibsen (fragmento)", no 98, 24 octubre 1900, p. 4. Excepto el artículo sobre Mallarmé recuperado en mi artículo citado y el presente "El espíritu francés", las demás colaboraciones se reprodujeron en otros medios y aparecen en distintos libros y recopilaciones darianas. 
fundamental: Azul... (1888), el primer fruto de su "iniciación" en los secretos de la lengua y la literatura francesa moderna, especialmente de la iniciación parnasiana, por el que recibió su primera consagración crítica internacional de parte del académico español Juan Valera. Darío hizo un uso constante, hábilmente variado y matizado del artículo de Valera y de su núcleo más importante y polémico: el diagnóstico sobre su "galicismo mental". Un uso que también estará en "El espíritu francés". Ya desde 1890 adoptó consciente y estratégicamente como lema el término "modernismo", una palabra que existía en español pero que tenía un matiz peyorativo, de afición excesiva a todo lo moderno, que él invirtió, reapropiándosela de manera positiva. Y desde ese mismo año, en que utilizó como prólogo para la segunda edición ampliada de Azul... el artículo de Valera, adoptó también como lema el "galicismo mental", asumiendo desafiantemente lo que este tenía de advertencia sobre los riesgos perturbadores o desnaturalizadores de la excesiva francofilia por parte sobre todo de los más hispanistas pero también de algunos americanistas.

Porque para entender "El espíritu francés" también hay que volver a subrayar que modernismo y afrancesamiento, modernidad y cultura francesa eran en ese tiempo para Darío prácticamente sinónimos. Y que Francia y sobre todo París representaban para él no tanto una nación singular y una capital concreta como un ideal o un mito de universalidad política, social y cultural. Octavio Paz explicó que el afrancesamiento de los modernistas "fue un cosmopolitismo: para ellos, París era, más que la capital de una nación, el centro de una estética" (Paz 1994: 1, 163); "era la libre elección no de un particularismo (el francés) sino de un universalismo"; "el afrancesamiento era una profesión de fe universalista" (Paz 1994: 4, 79) ${ }^{4}$. Haber nacido fuera de ese mítico centro de la modernidad universal era vivido por muchos modernistas de la periférica Hispanoamérica con sentimientos de carencia, insuficiencia, exclusión o exilio. La gran "ilusión" de Darío era entrar, integrarse, ser reconocido, pertenecer a él. Su modernismo responde a una "voluntad de participación en una plenitud histórica hasta entonces vedada a los hispanoamericanos" (Paz 1994: 3, 143). Aunque pronto intuye las enormes dificultades, obstáculos y riesgos de intentar ese asalto a su cielo, aún pueden más su esperanza y entusiasmo juveniles. También en 1890 escribe la biografía sobre su afrancesado y malogrado amigo chileno Pedro Balmaceda, "A. de Gilbert”: “¡Iríamos a París, seríamos amigos de Armand Silvestre, de Daudet, de Catulle Mendès [...], oiríamos a Renan en la Sorbona y trataríamos de ser asiduos contertulios de madame Adam; y escribiríamos libros franceses!, eso sí" (1950: 2, 163). Durante la década siguiente incluso se plantea, efectivamente, si escribirá en francés, idea que terminará abandonando. Su tarea será asimilar, adaptar, "pensar en francés y escribir en castellano". El "sueño" de ver París se cumple en la fugaz pero intensa visita del verano de 1893, que no hace más que aumentar su "deseo" por la capital de las capitales: "París era para mí como un paraíso donde se respirase la esencia de la felicidad sobre la tierra. Era la ciudad del Arte, de la Belleza y de la Gloria; y, sobre todo, era la capital del Amor" (1950: 1, 102). Con ese deseo como acicate vive y escribe durante el decisivo lustro bonaerense de 1893 a 1898, el de la renovada iniciación en el simbolismo, el de la campaña modernista, el del creciente reconocimiento continental. El lanzamiento en 1896 de Los raros y Prosas profanas es la demostración de su actualización y homologación con sus pares europeos, la prueba de que él, sobre todo él, más que ningún otro modernista, merece un sitio en la ciudad de la Gloria. En "Palabras liminares" se despide del "abuelo español de barba blanca", una representación del académico Valera y de los mantenedores más conservadores de la tradición española, con la burlona y famosa confidencia: "Abuelo, preciso es decíroslo: mi esposa es de mi tierra; mi querida, de París" (1967: 547). En su contestación de noviembre de ese año a las críticas de Paul Groussac sobre Los raros también confiesa abiertamente: "Mi éxito - sería ridículo no confesarlo- se ha debido a la novedad: la novedad ¿cuál ha sido? El sonado galicismo mental. Cuando leía a Groussac no sabía que fuera un francés que escribiese en castellano. Pero él me enseñó a pensar en francés: después, mi alma gozosa y joven conquistó la ciudadanía de Galia" (en Caresani 2013: 307). Aunque puntualiza: sí, ha imitado a todos los modernos franceses, pero ha logrado ser "original", no ha dejado de ser él mismo. Un par de meses después sigue identificándose así: "Yo, ciudadano de la Francia intelectual [...] más de una vez he manifestado mi cordial y mental galicismo" (cit. en Barcia 1968: 1, 57).

\footnotetext{
${ }^{4}$ Paz escribió estas dos últimas frases a propósito del afrancesamiento del grupo mexicano de los “Contemporáneos”, tan atacados como cosmopolitas y extranjerizantes por el nacionalismo de su país durante los años 20 y 30 del siglo XX, y de hecho Paz sigue las ideas del ensayista de Contemporáneos Jorge Cuesta, pero creo que son perfectamente aplicables a muchos afrancesados hispanoamericanos y (acaso esto se olvida) españoles, a los modernistas y muy señaladamente a Darío. En términos similares lo entiende Mario Siskind: "Para Darío, la cultura francesa es universalmente moderna (su particularidad es idéntica a la universalidad de la modernidad) y lo universal solo puede nombrarse en francés, o al menos a través de un imaginario francés"; "Para Darío, ser moderno es ser francés. Darío vacía a Francia de su contenido particular francés y la convierte en el significante de lo universalmente moderno" (Siskind 2016: 257, 279). También Ángel Rama adelantó que, como veremos, a Darío le costó mucho "descubrir que no había imitado a la cultura europea o a la francesa en particular, sino a la concepción que un fatal hispanoamericano podía hacerse, desde sus lejanas tierras, de lo que era la cultura de las metrópolis de ultramar en las que soñaba” (Rama 1973: 43).
} 
De sus muchas declaraciones de adoración a Francia, pocas más encendidas que la del 14 de julio de 1898, con motivo de la fiesta nacional en la embajada francesa en Buenos Aires. En el artículo correspondiente para La Nación, "La fiesta de Francia", celebra la gesta libertadora de la Revolución Francesa, génesis del mundo moderno, exalta la belleza y universalidad de su capital "Ante esa capital mágica se extiende un inmenso océano de ensueños. Allí vamos los peregrinos del amor y del arte, allí van todos los adoradores de la vida"; "no hay quien, por bárbaro o ignorado, no alimente el gran deseo de contemplar la ciudad soñada. París es el paraíso de la vida"), de su idioma ("El idioma de Francia es el nuevo latín de los sacerdocios ideales y selectos"; "la rosa de los cuatro vientos del espíritu. Su lengua es la verdadera lengua católica, en el verdadero sentido, la lengua del Universo"), incluso de sus mujeres, en las que ve encarnado el mito de la mujer y sobre las que dice, como un eco de su propio poema "Divagación": "la mujer de París: su nombre es Poliginia; comprende en sí a todas las mujeres, y es ella sola, es la mujer"' (Darío 1919: 123-127; cfr. Salinas 1975: 38-39 y 135; Siskind 2016: 258-259).

Pero el sentido celebratorio de "La fiesta de Francia" nace también como reacción ante una coyuntura de crisis que en el 98 afectaba a dos de los países latinos, doble crisis a la que Darío alude y a la que trata de responder positivamente. Por un lado el escándalo Dreyfus, con sus corrupciones políticas y reacciones antiintelectuales: "Pueden agitar el fondo de la fuente patria las maculadas manos de la política, los dedos de garra de la Administración prostituida; el alma francesa purifica el daño [...] y se alza, intacta, el antiguo oriflama, sin rasgadura ni lodo. El Arte y la Ciencia tienen allí sus torres de asilo, cuando la tormenta pasa. La Tierra necesita de Francia" (Darío 1919: 127). Por otro lado, y tampoco hay que olvidarlo para entender algunos matices de "El espíritu francés", el llamado "Desastre" o particular débâcle española. Dos meses antes de "La fiesta de Francia", el 2 de mayo, se había celebrado en Buenos Aires otra fiesta patriótica, la conmemoración del comienzo de la guerra de Independencia de España de la ocupación napoleónica. Pero se hizo en un ambiente dramático para los emigrantes españoles, en el mismo momento en que estaba consumándose el enfrentamiento y derrota de España ante los Estados Unidos en Filipinas y Cuba. Se organizó un acto de solidaridad latina en el que Groussac habló en nombre de Francia. Darío asistió y dejó la crónica "El triunfo de Calibán" (El Tiempo, 20 mayo 1898), en el que afirma su simpatía por la vieja y abatida España, "la Hija de Roma, la Hermana de Francia, la Madre de América", condena al joven monstruo Estados Unidos e insta a hacer efectiva la Unión Latina frente a la prepotencia anglosajona. En "La fiesta de Francia" tampoco deja de recordar esta circunstancia, espera también la solidaridad de Francia con España, y por primera vez hermana poéticamente a ambas naciones a través de los protagonistas de Cyrano de Bergerac, el reciente gran éxito de Rostand, que ya conocía, y del Quijote, ambos representantes del espíritu de la caballería y la poesía. Después de un tiempo de olvido o desdén, empezaba un proceso de reencuentro de Darío con España -en un principio todavía a través de la mediación francesa, "latina", una de cuyas más explícitas expresiones será el poema "Cyrano en España" (1899)-, pero que aún tardará unos años en consolidarse. Es en este contexto en el que hace la afirmación:

Los señores sabios nos demuestran que no existen razas; que la raza latina, más que ninguna otra, no existe. Muy bien. Yo soy de la raza en que se usa el yelmo del manchego y el penacho del Gascón [...]; yo soy de Grecia, de Italia, de Francia, de España (Darío 1919: 128).

Cuando publicó "La fiesta de Francia" es muy posible que le hubiera llegado el número de Revue de Revues con la "Enquête sur l'esprit français". Por las palabras que acabo de citar es casi seguro que, como vamos a ver enseguida, ya la hubiera leído. Debió pensar que estaba hecha para él. Se tomó su tiempo para escribir "El espíritu francés" y lo destinó, casi como una declaración, al número inaugural de El Sol del Domingo, la nueva revista bonaerense sobre la que tenía grandes expectativas. Darío contesta una a una a las tres preguntas de Finot. A las dos primeras, generales, especialmente arduas, sobre si existe el llamado "espíritu francés" y cuáles son sus rasgos característicos, responde con una trabajada exhibición de citas de autoridades decimonónicas, medievales, clásicas (introduce incluso, entre bromas y veras, tal vez para aligerar tanta erudición, referencias a alguna discutida fuente teosófica) $)^{5}$. Darío no duda: existe el "espíritu francés", si bien acepta que, como

\footnotetext{
${ }^{5}$ El despliegue enciclopédico del archivo occidental es frecuente en las crónicas de Darío. Aquí tal vez venga propiciado por la complejidad del asunto y la imposibilidad de responder directa y sencillamente a él, pero sobre todo es una demostración de su competencia para opinar como un escritor francés más, pues no solo dialoga con varios de los encuestados sino que parece superar a todos en conocimientos de fuentes y antecedentes. Como señala Günther Schmigalle, el gran editor de crónicas darianas: «Darío era un lector omnívoro, dotado de una memoria prodigiosa, y uno de sus secretos profesionales fue este de impresionar al público lector de La Nación con alusiones y referencias a textos franceses que nunca llegarían al
} 
argumentan Finot y bastantes de los encuestados, este no puede fundamentarse en una "raza francesa" en sentido estricto o etnográfico. De hecho recuerda que ya Ernest Renan en su famosa conferencia "¿Qué es una nación?" había negado esa posibilidad, y que más recientemente su "sabio amigo" Rémy de Gourmont, al escribir sobre la guerra hispano-estadounidense en Cuba, también había cuestionado que hubiese propiamente una "raza latina". Pero aunque Darío acepta esto, no por ello deja de afirmar rotundamente, aunque sin clarificar mucho los resbaladizos conceptos, que sí existe una "raza" en un sentido general de carácter o, mejor, un "alma" o, aún mejor, un "espíritu francés", que por origen y extensión es también un "espíritu latino". Y proclama:

Mas si nos referimos al "esprit” francés permaneceré con Zola y cien más, al pie de nuestro pabellón: es la herencia latina y gala. La caballería y la palabra, "rétores y luchadores" que dice ese buen caballero de la justicia: ello vino de Grecia a Roma y de Roma a Francia.

No es extraño que Darío, además de tener en cuenta el estudio de Finot, destaque muy especialmente la respuesta de Zola, cuyo prestigio como escritor en Argentina creció con su actuación en el caso Dreyfus, apoyada mayoritariamente por la opinión pública local (cfr. Lvovich 2003: 273-302). Todo lo que dijera Zola tenía autoridad moral e interés periodístico. Su respuesta a Finot, que Darío va a aprovechar un tanto libremente, es la siguiente:

Je me rappelle une page de Taine, que je regrette de n'avoir pas sous la main. Il y établit, selon sa méthode, par l'élimination des caractères transitoires, dus à des modes plus ou moins longues, que le fond même de l'esprit français est d'aimer les belles batailles et les beaux discours : en somme, guerrier et rhéteur.

Oui, si l'on veut. Mais ce sont là des caractères propres à tous les peuples latins, et je ne vois pas en quoi nos auteurs foncièrement nationaux, la grande lignée de Rabelais, Montaigne, Molière, La Fontaine, Voltaire, Diderot, sont des guerriers et des rhéteurs. Ils valent surtout par la raison, par la clarté, par la santé, par le libre examen, par la sagesse, par le culte ardent de la vérité et de la justice. Nous sommes des Latins, je le répète, et c'est là la grande famille à opposer aux familles du septentrion. Le sang gaulois n'a mis dans le sang romain, comme tout croisement heureux, que plus d'équilibre et plus de saine vigueur (Zola, en "Enquête..." 41; la cursiva es mía).

Darío, en un alarde de conocimientos, llega incluso a localizar el origen de esa afirmación de Zola. Más allá de que Taine la hubiera podido usar alguna vez, fue ya formulada por el poeta medieval Chrétien de Troyes, quien había reivindicado la pasión por la caballerosidad y el conocimiento, por los guerreros y "rétores» (retóricos u oradores) como una herencia que pasó de Grecia a Roma y de esta a Francia. En «La fiesta de Francia» Darío caracterizó el "alma francesa" por "el heroísmo, el soplo artístico" (Darío 1919: 126) y puso en relación a los caballeros y poetas Cyrano y Don Quijote. En "El espíritu francés" llama a Zola "buen caballero de la justicia" y es posible que, efectivamente, a juzgar por su carta a Finot, el Zola del contundente "J'accuse", atacado, encarcelado y exiliado por salir en defensa quijotesca de la inocencia de Dreyfus, se viera a sí mismo como una encarnación intelectual moderna de esa estirpe latina de guerreros y apasionados de la palabra, pero también de la razón, el libre examen, la verdad y la justicia.

A partir de aquí, Darío repasa las características normalmente atribuidas a la mentalidad y la literatura francesa, que los encuestados de Finot no dejaron de repetir (claridad, gusto, ligereza, gracia o alegría), y concluye que para él la esencia que las engloba a todas es el idealismo, el espíritu "ascendente y afirmativo", diferente del espíritu negativo de origen germánico propio de los países del norte. Si para Darío el "otro" frente al que se define Hispanoamérica es fundamentalmente los Estados Unidos, el otro de Francia es fundamentalmente Alemania y el otro de los países latinos son los pueblos germánicos y sajones. Cuatro años después, atendiendo a la "Enquête sur l'influence allemande" organizada por el Mercure de France, a la que sí fue invitado, responderá en nombre de "la América española" en términos muy similares: 
No, no puede ser simpático para nuestro espíritu abierto y generoso, para nuestro sentir cosmopolita ese país pesado, duro, ingenuamente opresor, patria de césares de hierro y de enemigos netos de la gloria y de la tradición latina.

Los eruditos de la última gaceta, os dirán que han aprendido que no hay raza latina, y que en Europa misma los elementos componentes de la nacionalidad española o francesa, son todo menos latinos en su mayor parte. "La nacionalidad latina, responderá Paul Adam, es toda de ideas, no de sangre". Nosotros somos latinos por las ideas, por la lengua, por el soplo ancestral que viene de muy lejos [...] Por más que se diga, somos, más que otra cosa, hijos mentales de Francia, de la civilización latina. Un impulso latino mantiene nuestro anhelo de libertad y de belleza. Los mismos defectos son heredados y tradicionales, cuando no reflejados o impuestos por una ley simpática (Darío 2004: 137141).

Pero más importante que las dos primeras preguntas de la encuesta tenía que ser para Darío la tercera: ¿puede un extranjero asimilarse ese espíritu y ser un escritor "francés"? A lo que contesta evidentemente que sí y pone varios ejemplos de recientes escritores hispanoamericanos, insistiendo en lo posible en aquellos que habían logrado un mínimo reconocimiento en Francia: además del caso más mundano de Lucio V. Mansilla, famoso en los salones de París; el de Augusto de Armas, a quien Darío había dedicado un artículo de Los raros y cuya obra poética fue reconocida por Banville; el de los compañeros modernistas Julián de Casal, alentado por Verlaine, y Manuel Gutiérrez Nájera; y el del prometedor Carlos Alfredo Becú. De ellos, solo De Armas había escrito en francés, pero todos habían asimilado como propio el aristocrático y poético "espíritu francés". (Otra vez deja fuera de la lista a Lugones, tampoco menciona a Leopoldo Díaz, Eugenio Díaz Romero u otros que más tarde reconocerá como los más "franceses" de los modernistas). Pero antes y después de todos ellos Darío se pone él mismo como ejemplo. Una vez más lleva la cuestión a un terreno personal. Como había dicho ante Leopoldo Alas "Clarín" y como empezó diciendo ante Groussac en "Los colores del estandarte": "Tengo por fin que tratar de mi obra y de mí mismo, pro domo mea" (en Caresani 2013: 307). Y una vez más cita el artículo de Valera, antes de afirmar, tal vez más rotundo y retador que nunca: "Yo como escritor soy mentalmente francés, y a mucha honra".

Darío termina pidiendo que los escritores que, como él, son espiritualmente franceses sean admitidos en la República universal de las letras francesas. Habla de reconocimiento, desde luego, de la máxima, más universal legitimación literaria que solo París podía otorgar, pero también y como consecuencia de ello, tal vez de algo aún más concreto. En 1897, una vez publicados Los raros y Prosas profanas, creía que había llegado el momento de dar un paso más en su carrera y trasladarse a Europa para, una vez allí, instalarse algún día en su deseado París. Contaba con que podría mantenerse como corresponsal de La Nación, pero también estaba ya intentando que José Santos Zelaya, el dictador liberal de Nicaragua, le concediese un puesto diplomático. Había hecho algunos estudios diplomáticos en Chile y había ostentado el cargo de cónsul general de Colombia en Buenos Aires. Aunque en ese tiempo en que la diplomacia no era aún una profesión muy reglada y las repúblicas hispanoamericanas solían usar a sus escritores como decorativa carta de presentación ante los países dominantes, el mayor aval de Darío era el prestigio creciente de su obra literaria. Por lo demás él siempre mantuvo una concepción romántica sobre el carácter excepcional del artista y una convicción muy personal sobre el trato preferencial que, a diferencia de lo que solía ocurrir, la sociedad y el Estado debían otorgarle. En "El espíritu francés" termina usando sus conocimientos generales sobre diplomacia y derecho internacional para solicitar, no sabemos si con extremada inocencia o extremada audacia, que Francia aplique una generosa excepción en su política de admisión de los extranjeros a aquellos intelectuales y artistas que han logrado adquirir la "ciudadanía espiritual" francesa. Al menos así parece él haber entendido la encuesta y el ensayo de Finot: que quien demuestre suficiente talento, dice, "debe de encontrar las puertas abiertas". ¿Qué acaba entonces realmente pidiendo Darío en "El espíritu francés"? ¿Algo así como la concesión de la nacionalidad francesa por "carta de naturaleza" a quienes hayan demostrado méritos artísticos y servicios excepcionales en beneficio del prestigio de Francia? Él estaba convencido de haber demostrado su magisterio poético con la publicación de Prosas profanas, el libro en el que se había puesto conscientemente no solo a la cabeza de los escritores hispanoamericanos sino a la altura de sus propios "raros" cosmopolitas y franceses, el libro que, soñaba, París reconocería como propio. Apenas mes y medio después todavía escribió en El Sol del Domingo: "Siga Francia desdeñosa con el producto de nuestras inculturas y miserias sociales; y abra sus puertas a nuestros espíritus superiores, que sobre las pequeñeces de la vida nacional, vuelan a la gran ciudad, centro de 


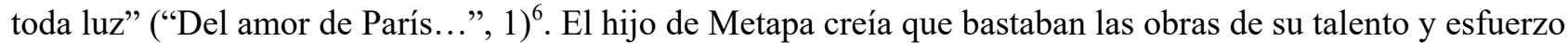
para superar la desventaja de su marginalidad geográfica y atraso histórico original y alcanzar un lugar en "la ciudad de la Gloria".

Resulta sin embargo obligado acabar con un breve epílogo desencantado. La relación de Darío con Francia y su literatura fue, como dijo Pedro Salinas, una historia de "amor no correspondido" (1975: 39). A su instalación en París en 1900, el año de la Exposición Universal, siguió su "decepción de París", que distintos críticos darianos han estudiado ${ }^{7}, \mathrm{y}$ que es un factor determinante de toda su evolución posterior. Apenas cabe aquí apuntar que ante la confrontación entre el "París libresco" y el "París real", y ante su conocimiento más prolongado y cercano de la sociedad y la política francesa, se multiplicaron sus denuncias sobre la decadencia del idealista "espíritu francés", síntoma de una crisis general de valores que, auguraba, terminaría llevando a Europa al desastre. Y que ante el vacío en que cayeron allí la edición parisina de Prosas profanas (1901) y sus sucesivos poemarios y libros de crónicas, ninguno de los cuales recibió una sola crítica o traducción por parte de un escritor francés, se redoblaron sus quejas sobre la ignorancia, los prejuicios, la indiferencia e incluso la mala fe de los hombres de letras franceses hacia lo foráneo, más aún si procedía de países que ellos tenían por "salvajes". "Llegué a París con todas las ilusiones, con todos los entusiasmos [...] Llegué, vi, quedé desconcertado", escribió en 1901, invirtiendo irónicamente la frase del conquistador (Darío 2008: 123). Darío, seguro de su propio valor, chocó con la estructura desigual del universo literario (Casanova 2001: 21-25 y passim) y sufrió la amarga experiencia de su exclusión y la de sus colegas hispanoamericanos de la idea misma que de lo literario tenían los países dominantes, una situación que en términos generales durará al menos medio siglo más, hasta el llamado "boom" de la literatura hispanoamericana: "A nosotros no nos ha tocado aún el momento", escribió también en 1901 (Darío 2001: 103). Un par de años después, en la crónica "Libros viejos a orillas del Sena" confesaba: "Mi reconocido orgullo ha recibido en esos mismos lugares importantes lecciones, ¡oh, mis colegas de América! Por allí he comprado unas Prosas profanas, con la dedicatoria borrada, a treinta céntimos. Los que enviáis libros a estos literatos y poetas, a estos 'queridos maestros', no sabéis que irremisiblemente vais a parar al montón de libros usados de los muelles parisienses" (187). Y en 1907: "Yo he sido más apasionado y he escrito cosas más 'parisienses' antes de venir a París que durante el tiempo que he permanecido en París. Y jamás pude encontrarme sino extranjero entre estas gentes" (1950: 1, 464).

El fracaso de sus expectativas juveniles cifradas en París, la quiebra de su fe en la abierta y generosa universalidad francesa y la comprobación de las insalvables asimetrías que seguían rigiendo las relaciones literarias mundiales, le llevaron a redefinir o matizar sus sentimientos de pertenencia y a replantearse sus estrategias de supervivencia vital y literaria. Terminó de reconciliarse con España, a cuyos nuevos poetas reconoció como discípulos, a cuyos lectores volvió a dirigirse y donde se refugió en algunos de los momentos más duros de la crisis permanente que fue su etapa europea. Sin desprenderse de su identidad latina, en Cantos de vida y esperanza puso el acento en lo hispánico. A partir de entonces atenuó mucho su entusiasmo por las novedades de la literatura francesa, cuyo gran ciclo consideraba cerrado, y se mostró más interesado en presentarse como clásico moderno que como modernista afrancesado. En Historia de mis libros, al volver sobre Azul...y la Carta americana de Valera, matizó: “"VValera observa, sobre todo, el completo espíritu francés del volumen [...] Cierto; un soplo de París animaba mi esfuerzo de entonces; más había también, como el mismo Valera lo afirmara, un gran amor por las literaturas clásicas y conocimiento de 'todo lo moderno europeo'. No era, pues, un plan limitado y exclusivo" (1950: 1, 198-199). Y al citar "Abuelo, es preciso decíroslo: mi esposa es de mi tierra; mi querida de París", cree necesario explicar: "En el fondo de mi espíritu, a pesar de mis vistas cosmopolitas, existe el inarrancable filón de la raza; mi pensar en mi sentir continúan un proceso histórico y tradicional" (1950: 1, 206-207).

En sus últimos años añoró con fuerza volver a instalarse en Buenos Aires, la otra Cosmópolis, el París del Plata, mucho más acogedor para él que el París de Sena, donde había pasado la época seguramente más feliz de su vida, donde contaba con La Nación y su público más fiel, la capital de un país en cuyas potencialidades y capacidad para encabezar en el futuro "el espíritu latino" tenía una fe absoluta. Pero con todo esto y más, lo

\footnotetext{
6 "Del amor de París y la influencia de la caña de azúcar, del café y de los cueros en el rastaquerismo" se publicó, como dije, en el no 7 de El Sol del Domingo, en respuesta a algunas opiniones de Pedro Emilio Coll en el Mercure de France, y a su vez desencadenó el intercambio polémico de Darío con Unamuno sobre la influencia francesa en Hispanoamérica, que requeriría un estudio aparte. El artículo fue reproducido al año siguiente en El Cojo Ilustrado (cfr. Moser y Woodbridge 1964: 34-37).

${ }^{7}$ Cfr. Contreras 1930: 123-124; Rama 1973: 31-61; Molloy 1972: 33-67; Arellano 1993: 99-113; Noguerol 1998: 165-188; o Siskind 2016: 245-290. Y sígase la fundamental labor de rescate de las crónicas europeas de Darío llevada a cabo por Schmigalle y, entre otras, su introducción a Darío 2008: 10-15. Para un marco literario finisecular más general, véase, también entre otros, Pera 1997 o Colombi 2008: 544-566.
} 
cierto es que nunca renunció a seguir de corresponsal en el inconquistable pero irresistible París, un centro que seguía ignorándolo, pero de cuyo prestigio y proyección en el mercado literario de lengua española él seguía necesitando, como muestra su aceptación de la dirección de Mundial Magazine (París, 1911-1914). En medio de todo, también se esforzó en distinguir, como había hecho en "El espíritu francés", entre el alma y el espíritu, entre el particularismo y la universalidad francesa: “¡Ay! -escribirá en 1910- Ha sufrido algo mi admiración, no por la Francia, a la que amaré y veneraré siempre hasta mi último aliento, como la fuente de toda generosidad, de toda grandeza y de toda belleza, sino por la administración francesa" (Darío 2011b: 268). Y cuando Francia se vio amenazada, cuando llegó la profetizada Gran Guerra, no dejó de volver a proclamar una vez más las virtudes del "espíritu francés” y a identificarlo con la libertad y universalidad del espíritu humano.

\section{Rubén Darío: "El espíritu francés”, El Sol, Buenos Aires, 4 septiembre 1898, p. 1. ${ }^{1}$}

Hace pocos meses, en la conocida y notable Revue des Revues, de París, se promovió una interesantísima investigación o enquête sobre el espíritu francés. ¿Existe dicho espíritu? ¿Cuáles son sus condiciones esenciales? ¿Puede un extranjero ser un escritor francés? He ahí las proposiciones por resolver. Las respuestas de varios de los escritores de París fueron publicadas, y La Nación dio a sus lectores, en Buenos Aires, un extracto de aquellas opiniones ${ }^{2}$. La última, alfabéticamente, era la de Émile Zola, cuya actitud reciente le ha conquistado aquí, como en todas partes, entre sus numerosos admiradores una nueva aureola.

En esa respuesta corta y maciza Zola aprovechó el momento para proclamar la virtud patente de la raza latina. M. Finot, en un estudio sesudo y lleno de buena simiente que publica a continuación de la enquête, niega por razones científicas la existencia de una "raza francesa" 3 . Mi sabio amigo M. Rémy de Gourmont, no hace mucho tiempo y a propósito de la cuestión hispano-yankee, demostró lo erróneo de la creencia en una raza latina. Los españoles lo propio: mil sangres diversas corren por sus venas, y mil tradiciones distintas confirman la hibridez; los únicos que podrían afianzar su derecho serían los italianos o mejor dicho los habitantes de una corta parte de la península. Tal, más o menos, en uno de los recientes "epílogos", tan profundos como amenos, del Mercure 4 . Pero antes, ya Renan había negado que pudiese haber una raza pura, cualquiera que fuese, considerándola etnográficamente ${ }^{5}$. Ante tales

${ }^{1}$ Edito el artículo anotándolo críticamente; solo actualizo la acentuación y la puntuación, añadiendo signos de apertura en las frases admirativas y exclamativas; y corrijo las erratas evidentes en nombres, palabras y títulos franceses y en citas latinas, errores que cabe atribuir fundamentalmente a descuidos o malentendidos de los tipógrafos de El Sol ante el manuscrito que entregaría Darío. En este sentido sustituyo "Bouchez de Perthes" por Boucher de Perthes, "Froissard" por Froissart, "Freijeinet" por Freycinet, vraie-gout por vrai-goût, calenbourg por calembour, Journal Amussant por Journal Amusant; y la frase "inmode ratas forum crápulas atque ebrietates" por inmoderatas forum crapulas atque ebrietates.

${ }^{2}$ Se trata, como quedó dicho en la introducción, de "Enquête sur l'esprit français", Revue des Revues, vol. XXVI, 1 julio de 1898, pp. 1-41; y de “El espíritu francés", La Nación, Buenos Aires, 29 julio de 1898, pp. 2-3.

${ }^{3}$ Jean Finot, "La formation, le présent et l'avenir de l'esprit français", Revue des Revues, vol. XXVI, 1 julio de 1898, pp. $42-59$.

4 "Nosotros admiramos a Rémy de Gourmont en América Latina; conocemos, quien más, quien menos, su obra", escribió Darío en 1910 (Darío 1950 : 2, 549). Él seguía sus escritos en la revista y editorial del Mercure de France desde al menos 1893. Su Le Livre des Masques fue uno de sus grandes modelos y fuente de información para Los raros. En 1897 le envió un ejemplar de Prosas profanas y, según contó, Gourmont le contestó alabándole el título inspirado en su Latin mystique: "C'est une trouvaille" (Darío 1950: 1, 118 y 382). De ahí el no disimulado orgullo de calificarlo como "mi sabio amigo". Gourmont en su respuesta a la encuesta de Finot no rechazó que hubiera algo así como un carácter medio francés, cierta suma de cualidades y defectos tradicionales; en cuanto a la literatura francesa, para él su única característica era estar escrita en idioma francés, algo extremadamente difícil de adquirir por un extranjero; y terminaba afirmando la realidad beneficiosa de la mezcla racial en Francia: "la vitalité intellectuelle de la France est due au mélange perpétuel des races, qui y fut toujours très actif depuis les temps historiques, depuis la conquête romaine" ("Enquête..., 13). Pero el artículo al que aquí se refiere Darío es "Les Races latines", que Gourmont publicó dentro de su serie "Épilogues" del Mercure en junio de 1898, en plena guerra hispanoestadounidense en Cuba, ocasión que propició todo tipo de elucubraciones sobre las razas latinas y sajonas, conceptos que para él no se sostenían. Tanto franceses como españoles eran “le résultat d'un mélange fort complexe [...] Il n'y a pas aujourd'hui de race latine, en dehors peut-être des faubourgs de Rome, de la campagne romaine, de Naples et de ses environs, de quelques petites régions [...] il n'y a pas de races latines et il n'y a qu'un pays de tradition latine, l'Italie» (Gourmont 1903: 253-256). Cuando en 1903 Darío lo visitó por primera vez en París y escribió su crónica "Rémy de Gourmont" para La Nación, incluida en Opiniones, volvió sobre los “'epílogos', tan profundos como amenos": "los incomparables Épilogues, reflexiones, consideraciones, concreciones filosóficas, que, reunidos a la manera de algunos libros de Nietzsche, forman un trabajo de alto valer, macizo y firme bajo su apariencia ligera" (Darío 1950, I: 387). Ambos seguirían intercambiando algunos favores hasta 1907, cuando Darío le dedicó el romance “A Rémy de Gourmont", incluido en El canto errante, mientras esperaba que Gourmont sacara una antología de su poesía en el Mercure que finalmente no se realizó. Tampoco esta relación, una de las más importantes que Darío mantuvo con un escritor francés contemporáneo, alcanzó el nivel de amistad y colaboración de igual a igual.

${ }^{5}$ Darío se refiere a «¿Qué es una nación?», la célebre conferencia que Ernest Renan pronunció en 1882, en el conyuntura específica de la disputa por Alsacia y Lorena entre Francia y Alemania, y que se convirtió en una de las piezas clásicas del interminable debate sobre el concepto de nación. En ella Renan se opuso a la concepción cultural de nación (basada en la raza, el territorio, la religión, la lengua o la comunidad de intereses) y defendió una concepción política de nación moderna como "plebiscito de todos los días», como una construcción basada esencialmente en la 
opiniones, $-\mathrm{y}$ así buscáseis un refugio en la Biblia-, ¿se arriará por ello la bandera latina? Podría estarse de acuerdo: toda raza humana ha dejado de ser pura, estrictamente hablando, desde que las "hijas de los hombres" se ayuntaron con los "hijos de Dios"... No sonriáis.

Sabéis bien que de esa unión brotó una raza gigantesca cuya aparición otros sabios han supuesto, o dado por cierta, ante los hallazgos de Boucher de Perthes y del juez Wert; la cual raza sería a la de los hombres de hoy lo que los mammuths a nuestros elefantes..., si de tan alto arranca la mixtura, ¡calcular con el tiempo transcurrido de Sem, Cam y Jafet hasta nuestros días! Mas si nos referimos al "esprit" francés permaneceré con Zola y cien más, al pie de nuestro pabellón: es la herencia latina y gala. La caballería y la palabra, "rétores y luchadores" que dice ese buen caballero de la justicia: ello vino de Grecia a Roma y de Roma a Francia a formar ese "esprit" que, por más que se diga, no ha vuelto a salir de alli ${ }^{7}$. Ya lo cantó el bravo Cristian de Troyes, cuya voz podéis escuchar, allá en las lejanías del siglo decimotercio:

\author{
Or vous ert par ce livre apris \\ Que Gresse ot de chevalerie \\ Le premier los et de clergie; \\ Puis vint chevalerie à Rome, \\ Et de la clergie la some, \\ Qui ore est en France venue. \\ Diex doinst qu'ele i sois retenue, \\ Et que li lius li abelisse \\ Tant que de France n'isse \\ L'onor qui s'i est arestée! ${ }^{8}$
}

voluntad comunitaria de pertenencia en el presente, aunque apoyada en un sentimiento de continuidad con el pasado (que Renan no deja de reconocer como selectivo) y en un proyecto de futuro. Darío se vale concretamente de sus afirmaciones: «La considération ethnographique n'a donc été pour rien dans la constitution des nations modernes [...] La vérité est qu'il n'y a pas de race pure" (Renan, 1882: 15). También el historiador del arte Eugène Müntz las había citado en su respuesta a Finot ("Enquête...", 18).

${ }^{6}$ Todo este inciso irónico sobre la mezcla racial, tan antigua como la propia humanidad, procede en realidad de Madame Blavastky, esa "otra sabia" fundadora de la Teosofía, en cuyas enseñanzas Darío se inició en Buenos Aires junto a Leopoldo Lugones, entre sentimientos encontrados de incredulidad, fascinación y miedo, y hacia cuya "charlatanería" mostró en algunos momentos cierto desdén (cfr. Rama 1973: 25-31). En Isis sin velo (1877) Helena Blavastky pretende hacer un estudio comparado entre las ciencias y las religiones que vaya más allá de las formas oficiales y reduccionistas de entenderlas, y poner al descubierto la verdad oculta, original y universal. Entre otras cosas, intenta demostrar que los hombres primitivos, "hijos de Dios" e "hijas de los hombres", eran gigantes, tal como, según ella, coinciden en señalar los libros sagrados - Génesis (que es también donde se habla de los citados Sem, Cam y Jafet, los tres hijos de Noé que salieron del arca y repoblaron la tierra), Vedas o Edda- y como confirman los descubrimientos fósiles del paleontólogo Jacques Boucher de Perthes en Francia y del magistrado E. P. Wert en Missouri (cfr. Blavastky 1924, 1: 171 y 227; 2: 11-12). A propósito de las fuentes teosóficas del cuento "El caso de la señorita Amelia", cuya primera versión se publicó en 1894, Günther Schmigalle (2014: 201, n. 10) se preguntaba si para entonces Darío realmente habría leído Isis sin velo. El presente artículo parece confirmar que al menos cuatro años después sí lo había hecho.

${ }^{7}$ En la presentación he reproducido la respuesta a Finot de Emile Zola, "corta" aunque tal vez menos "maciza" de lo que Darío dice, y he tratado de explicar las razones por las que este le otorgó una especial relevancia. Su caracterización de Zola como "buen caballero de la justicia" estará implícita en su crónica "El Cristo de los Ultrajes" (1899), escrita como reacción a la segunda condena del capitán Dreyfus e inspirada en el cuadro del mismo nombre que Henry de Groux, su futuro amigo y ardiente dreyfusista, había pintado en 1890. En esta crónica Zola aparece como una de las inteligencias que ha mantenido la "tradición de nobleza y de grandeza moral" de Francia en "un momento en que el brillo del espíritu francés ha palidecido ante el mundo". Véase, entre los varios estudios sobre Darío y el caso Dreyfus, la explicación y edición de dicha crónica por Schmigalle (2011-2012: 157-185). En su necrológica "El ejemplo de Zola” (1902), refiriéndose esta vez a la versión del mismo Groux "Zola de los ultrajes" (1898), rendirá tributo a "su magnífica valentía, su heroísmo, su respetabilidad intelectual, su soberano quijotismo. Los yangüenses quisieron apalearle, apedrearle. Así le ha pintado Henry de Groux en una tela dantesca. Mas ese quijotismo estaba armado de potente lógica, de decisión, de fortaleza" (Darío 1950, I: 239). Cabe añadir que Darío siguió aplicando la caracterización de «rétores» a los latinos -franceses fundamentalmente, pero también españoles e hispanoamericanos-, para contrastarlos, tanto en sentido positivo como negativo, con los anglosajones. Por ejemplo, en su crónica "En Londres" (1901) define el carácter de los ingleses: "no son verbosos como nosotros los latinos, raza de rétores" (Darío 2005b: 28); en su conciliadora y discutida "Salutación al águila" (1906), pide al símbolo del poder estadounidense la virtud de su fuerza práctica, con la que contrarrestar la ilusa verbosidad latina: "Tráenos los secretos de las labores del Norte,/ y que los hijos nuestros dejen de ser los rétores latinos, / y aprendan de los yanquis la constancia, el vigor, el carácter" (Darío 1967: 708). En "De oratore" (1910) termina sin embargo: "Dios de a la Francia oradores como los que ha tenido antaño, puesto que ella es portadora de la palabra del mundo" (Darío 2011b: 260).

${ }^{8}$ Con casi toda seguridad Darío tomó la cita del escritor medieval francés Cristian o Chrétien de Troyes de la antología histórica Les poëtes français. Recueil des chefs-d'œuvre de la poésie française depuis les origines jusqu'à nos jours, dirigida por Eugène Crépet. Concretamente del capítulo sobre el siglo XIII (de ahí que sitúe a Chrétien de Troyes en ese siglo y no el XII, como le corresponde) escrito por Louis Moland, quien presenta esa época como la más hermosa de la Francia medieval: "À aucune autre époque de notre histoire [...] la suprématie morale et intellectuelle de la France ne fut plus universellement établie et acceptee en Europe. Elle-même avait du reste parfaitement conscience du rôle qui lui appartenait parmi les nations. Elle revendiquait fièrement l'héritage de la Grèce et de Rome. C'est là une des pensées les plus fréquemment exprimées par les écrivains du temps" (en Crépet: 76-77). A continuación transcribe el mismo fragmento de Chrétien de Troyes usado por Darío y ofrece la siguiente versión actualizada: "Il vous sera appris par ce livre que la Grèce eut le premier renom de chevalerie et de savoir. Savoir et chevalerie vinrent ensuite à 
Sería imposible no reconocer la efectividad del espíritu del alma francesa o más bien dicho: del espíritu y del alma franceses. Comúnmente se da el mismo sentido a ambas palabras: hay empero diferencia entre una y otra. El nephesh de la Biblia corresponde a la psique; pero no el nous platónico, que deriva más directamente de la fuente divina. Este es el espíritu, el "esprit". Aplicada a las naciones esta diferencia yo diría que, del mismo modo que en los humanos, al alma corresponden el carácter y la acción, y al espíritu la inspiración y el vuelo ${ }^{9}$. El alma de la Francia ha podido alguna vez emigrar, sufrir algunas variaciones y eclipses: el espíritu ha permanecido siempre en el fondo anidado en la raíz latina. Cuando el príncipe de Ligne expresa que de Atenas ha ido la Francia a Esparta pasando por el país de los Hunos, no dudéis de que es el alma de lo que se trata ${ }^{10}$. El alma corresponde más a la idea de la patria. En los tiempos medioevales no existía la patria francesa. Froissart no sabía lo que era un francés. La gran serie de nuestros reyes, dice Sainte-Beuve, los Luis IX, los Carlos V, los Luis XII y aún Francisco I contribuyeron a formar la idea patriótica, que había adquirido popularidad encarnada en Juana de $\operatorname{Arco}^{11}$. Pero el espíritu ya existía. Él es quien, según la bella imaginación de Renan, acompañaba a los sanos campesinos borgoñeses que mientras las tinieblas del año 1000 llenaban de espanto al mundo, tenían vino y sol, y reían y cantaban cantos ${ }^{12}$. Si hoy el alma de Francia está enferma, si pasa por una palpable y tremenda crisis, tened por seguro que el espíritu la salvará. El espíritu va en la lengua por todas partes y en todas partes será el mismo; no podrán contra él ni climas ni medios. Séneca (Consolat. Helv. II) nos dice cómo la lengua de los macedonios sería entre la India y la Persia, a las orillas del Ponto en las colonias. Asia se poblaba de atenienses, el país sículo era griego; había tirios en África y cartaginenses en España, griegos en Galia y galos en Grecia. Mil causas hay que obligan a dejar la patria nativa y buscar otra. Estos éxodos son incesantes en la vida de la humanidad ${ }^{13}$. Y en todos los lugares el espíritu del hombre está en su sitio.

El espíritu francés es ciertamente difícil de definir, mas esa flor es inconfundible en la flora moral del mundo. Para apreciarlo, y gustarlo en toda su intensidad hay que haber recibido particular don de la naturaleza. ¿Cuáles son sus cualidades especiales? ¿Claridad? En lo referente a los escritores, los tienen todas las literaturas, transparentes como cristales, sobre todo los españoles. ¿El "gusto" es exclusivamente francés? Los españoles han proclamado la prioridad de su "buen gusto"; pero después de que existiera, según bien observa Borinski, apoyado a su vez en Trevisano, un vrai-goût francés y

Rome ; maintenant le savoir est venu en France. Dieu fasse qu'il y soit retenu, et que le lieu lui plaise tant que jamais de France ne sorte l'honneur qui s'y est arrêté !» (77).

${ }^{9}$ Darío mostró una concepción básicamente dualista del hombre, como ser compuesto de cuerpo y alma, esta última poéticamente nombrada en sus poemas y cuentos con la forma latinizada y más infrecuente de "Psiquis" y esteticistamente imaginada como princesa, mariposa o Hipsipila. Sin embargo, a esta concepción dualista, de raigambre platónica y cristiana o, si se quiere, paulina, a menudo conflictiva, sobre todo para la sexualidad, Darío sumó sincréticamente otros matices procedentes de diversas tradiciones espirituales difíciles de precisar. Aquí empareja el concepto hebreo "nephesh" y el griego "psique", que vienen a coincidir en significar aliento o soplo vital, y los diferencia de "nous", término que en Platón y otros filósofos griegos se refiere a la inteligencia o parte más elevada y divina de la realidad. Con ello introduce una sutilísima distinción entre el "nephesh", "psique" o "alma" de Francia, que relaciona con su particular e histórico carácter y patriotismo, y el "nous", "esprit" o "espíritu" francés, que es el que le interesa destacar y que hace corresponder con lo universal y eterno, la razón, el arte y el idealismo.

${ }^{10}$ Darío cita, un tanto descontextualizadamente, a Charles-Joseph de Ligne, aristócrata, militar, diplomático y memorialista de la época ilustrada y napoleónica. En un ensayo sobre el ejército francés durante los tiempos revueltos de la Revolución, con su mezcla de heroísmo, barbarie y civilización, el príncipe de Ligne afirmó: "D’Athènes la France a été à Sparte, en passant par le pays des Huns : car il y a eu de l'Attila, du Sylla, après avoir commencé par du Catilina"” (1828: 4, 141-142). Es muy posible que Darío tomara la cita del ensayo "Le prince de Ligne" del crítico Charles-Augustin Sainte-Beuve (1867: 8, 213). Al menos es seguro que tomó de Sainte-Beuve las opiniones siguientes.

${ }^{11}$ Darío sigue aquí casi literalmente el ensayo de Sainte-Beuve "Sully, ses Économies royales ou Mémoires": "Au Moyen-Age, ce mot de patrie existait peu : on suivait le seigneur féodal ; on se battait pour ou contre ceux qui étaient déjà ou qui devaient être des compatriotes. Le chevaleresque historien Froissart ne sait pas ce que c'est que d'être un Français. La grande lignée de nos rois, les Louis IX, les Charles V, les Louis XII et même les François Ier, en rassemblant sous leur main la France et en augmentant les fonds de la nation, contribuaient cependant, de siècle en siècle, à jeter les fondements de l'idée de patrie. Cette idée avait déjà pris dans le personnage héroïque de Jeanne d'Arc une popularité ineffaçable" (1867: $8,178)$.

${ }^{12}$ Renan en su "Conférence faite a l'Alliance pour la propagation de la langue française le 2 février 1888 ” entona un panegírico del francés como idioma de la civilización, el amable escepticismo y la alegría, y dice: "Je songe souvent que, pendant cette sombre première moitié du moyen âge, où toute joie du réel sembla perdue, le paysan bourguignon ou aquitain continua de boire son vin et de chanter ses joyeuses cantilènes, sans se soucier du grand rêve surnaturel qui séduisait le reste du monde" (1892: 264).

${ }^{13}$ Darío recurre un poco forzadamente a Consolación a Helvia, la epístola en la que el filósofo estoico Séneca consuela a su madre ante las desgracias familiares y su propio exilio. Uno de sus argumentos para restar dramatismo a este último es la inevitable y constante movilidad humana: "Verás que los pueblos y naciones han cambiado de patria. ¿Qué significan esas ciudades griegas en medio de países bárbaros? ¿qué significa esa lengua macedónica hablada entre la India y la Persia? La Scitia y toda esa región de naciones feroces e indómitas nos muestran ciudades de Acaya construidas en los litorales del Ponto [...] El Asia está llena de Atenienses; Mileto ha derramado ciudadanos en setenta y cinco ciudades diferentes. Toda la costa de Italia, bañada por el mar inferior, fue la Grecia mayor. El Asia reivindica a los Toscanos; los Tirios habitan el África; los Cartagineses, la España; los Griegos se han introducido en la Galia; los Galos, en la Grecia [...]. Evidente es que nada permanece en el punto en que nació: el género humano se mueve continuamente, y todos los días cambia algo en este vasto conjunto" (Séneca, 1884: IV). 
antes un gustus latino ${ }^{14}$. ¿La ligereza? ¿La gracia? Sobre todo eso hay un algo inasible e inanalizable, que marca inconfundiblemente el origen. Sobre civilización y costumbres, se distingue, se reconoce y se admira la superioridad del espíritu francés. Frangui dirá el bárbaro persa; franchute dirá el último indio de la América Central, y ellos saben lo que dicen. La apreciación del espíritu francés, por otros aspectos, no ha sido siempre la misma. Sostiene perfectamente Rémy de Gourmont que un alemán solo puede comprender y ver en la más sencilla caricatura francesa el lado lujurioso ${ }^{15}$. Yo agregaría que eso puede aplicarse a la mayor parte de las naciones. Entre nosotros el "esprit" francés —y eso aún entre gentes cultas - si es en las letras, se aprecia únicamente en su faz burlesca, en el equívoco calembour o en lo subido de color. Si es en el arte cualquier burgués (todos lo son) que le preguntéis por dicho espíritu, os señalará los hemisferios de Mars en el Journal Amusant ${ }^{16}$. Teniendo los franceses tan buenos vinos y tan bellas mujeres, la fama ha sacado la consecuencia y ya Polibio (Hist. Lib. II) les achacaba inmoderatas forum crapulas atque ebrietates ${ }^{17}$. Esta fama de ligeros, algo dudosa para Stendhal ${ }^{18}$, se ha esparcido por los cuatro vientos, no sin envidia de todos los países políticos de la tierra. El mariscal de Villars, que era buen voto, llamaba a la alegría "el alma de la nación"19. En verdad, la alegría de otras naciones comparada con la de Francia se parece a la tristeza. No puedo menos que recordar un harmoniosísimo discurso que Renan pronunciara hace diez años en una fiesta de la alianza para la propagación de la lengua francesa. Es un ramillete del más fino espíritu. "¡Ah, señores, exclamaba, cuánta alegría se iría de este mundo el día en que se fuera el francés!" "Enseñad a todas las naciones a reír en francés" ${ }^{\prime 2}$. Y todo el mundo comprende la excepcionalidad sutil de esa alegría. El genio de la nación que era para Montesquieu: las costumbres y el carácter de esprit de los distintos pueblos, dirigidos por la influencia de una misma corte o de una misma capital, está visible en Francia, bajo la superioridad de París ${ }^{21}$. El espíritu francés es ascendente y afirmativo. Es su principal diferencia del espíritu septentrional, que habla por los labios de Mefistófeles: Ich bin der geist der stets verneint ${ }^{22}$.

Un extranjero puede asimilarse el espíritu francés y ser un escritor francés aun escribiendo en otro idioma, ipensar en francés! Hablando desde el punto de vista nuestro, recomendaría al respecto el estudio que sobre el libro Azul..., de quien escribe estas líneas, publicó el académico español D. Juan

${ }^{14}$ Las opiniones sobre el controvertido asunto estético del "buen gusto" que habían expuesto el historiador literario alemán Karl Borinski y antes el italiano Bernardo Trevisano le pudieron llegar a Darío por distintos medios. Entre ellos, la completa y entonces reciente reseña crítica de Arturo Farinelli: “Trevisano había afirmado en su introducción a Muratori: Reflessioni sopra il buon gusto (Venecia, 1736) que los españoles, más expertos y acertados que otros en el uso de las metáforas, habían hallado la palabra 'buen gusto'. Borinski acepta sin más ni más la opinion de Trevisano, en su Poetik der Renaissance (p. 308), añadiendo todavía que ya los latinos reconocían un 'gustus' y los franceses distinguían un 'vrai-goût' antes de Gracián" (Farinelli 1896: 47).

${ }^{15}$ Gourmont en su respuesta a Finot empezaba diciendo cómo las diferencias entre franceses, ingleses y alemanes podían apreciarse en sus diferentes tipos de humor y observaba: "dans nos plus innocentes gauloiseries, un Allemand ne voit et ne comprend que l'interprétation luxurieuse" ("Enquête...", 11).

${ }^{16}$ El ilustrador belga Maurice Charles Mathieu Bonvoisin, conocido como "Mars", fue un asiduo y popular colaborador de los grandes periódicos ilustrados franceses e ingleses de la Belle Époque, entre ellos el semario parisino Journal amusant. Sus escenas humorísticas de la vida mundana y elegante presentan, como dice Darío, ciertos aspectos "subidos" de tono para la época, como sus difundidas imágenes de mujeres de prominentes pechos o "hemisferios", especialmente llamativas bañistas en las temporadas de playa.

${ }^{17}$ Como se verá enseguida, Darío menciona directamente a Don Francisco de Quevedo y Villegas, “el más fuerte de todos” los ilustres clásicos españoles, como había dicho en "Palabras liminares" de Prosas profanas. Concretamente su libelo antifrancés Carta a Luis XIII, en el que Quevedo recurre a la autoridad del griego Polibio, quien en su Historia de Roma descalifica con frecuencia a los galos. Darío usó con toda seguridad la edición de la Carta a Luis XII de la Biblioteca de Autores Españoles de Rivadeneira, colección que, como recordó en su Autobiografía, manejaba desde su temprana juventud. Allí es donde encontró la siguiente cita de Polibio: "quod frecuenter accidere Gallis consuevit, ob inmoderatas eorum crapulas, atque ebrietates (lib. 2)", que el propio Quevedo traduce así: "lo que frecuentemente suele acontecer a los franceses por sus demasiadas glotonerías y embriaguez" (Quevedo 1859: 262).

${ }^{18}$ Stendhal se pregunta en su Vie de Rossini: “Serait-ce que le peuple français est, dans le fait, l'un des moins légers de l'univers ? Les philosophes, qui lui ont décerné si souvent ce titre de léger, ont-ils pénétré plus avant que la forme de son habit ou la coupe de ses cheveux ?" (1929: 82).

${ }^{19}$ Darío vuelve a basarse en Sainte-Beuve, concretamente en su ensayo «Le maréchal de Villars», sobre Claude Louis Hector de Villars, Mariscal de Francia durante el reinado de Luis XIV: «La gaieté, que Villars appelait 'l'âme de la nation', il ne négligea rien non plus pour la leur rendre, et il en avait lui- même sa bonne dose» (1870: 107).

${ }^{20}$ En su ya citada conferencia de 1888 sobre la lengua francesa Renan dice: “Ah ! Mesdames et Messieurs, que de joie s'en irait de ce monde, le jour où le français s'en irait ! Conservez-le, conservez-le [...] Apprenez à toutes les nations à rire en français. C'est la chose du monde la plus philosophique et la plus saine" (1892: 263-264)

${ }^{21}$ En el pensamiento de Montesquieu sobre la personalidad de las naciones (“J'apelle genie d'une nation les moeurs et le caractere d'esprit de differens peuples dirigés par l'influance d'une meme cour et d'une meme capitale", en Montedite I, 348), a Darío le interesa subrayar la importancia de la capital, en este caso París, metonímia de la universalidad de Francia.

22 "Yo soy el espíritu que siempre niega" es la famosa respuesta de Mefistófeles a Fausto en la primera parte de la tragedia de Goethe. Ya en su muy juvenil poema "Espíritu" (1882), Darío hacía clamar al hombre contra este personaje, al que presentaba como personificación del materialismo y la desesperanza, de la negación de Dios y el ideal: “¡Mefistófeles! -grita el hombre airado./ ¡Mefistófeles cruel!/ ¡Genio eterno!... ¡Gigante dibujado/ por goéthico pincel!// Mefistófeles cruel: dime, te ruego,/ ¿dónde hallo al Dios que brilla? [...]// Mefistófeles cruel: dime tú, ¿dónde/ hallo alma, hallo razón?...” (Darío 1967: 100). 
Valera en sus Cartas Americanas. En esa obra proclama el galicismo mental de un autor latinoamericano, y al mismo tiempo niega en absoluto que semejante influencia pueda observarse en un español -ni en el abate Marchena, ni en Ochoa, que escribieron en francés y vivieron largo tiempo en París, encuentra él que se haya menoscabado un españolismo que nadie les arranca "ni a veinticinco tirones" 23 .

Los hispano-americanos que, por causas que saltan a la vista, tenemos hoy la necesidad, como dice Pedro Emilio Coll, de comer ideas, las recibimos de todas partes pero principalmente de Francia. Somos cosmopolitas y políglotas, pero sobre todo lo que más influye en nosotros y lo que mejor asimilamos, es lo francés ${ }^{24}$. En nuestras costumbres sociales -el salón- como en todas las aristocracias de la tierra lo francés es lo que más se imita y sigue. En el dominio del pensamiento, aun dando saltos peligrosos, y si queréis ilógicos, hemos tenido antes que España, el reflejo de las últimas manifestaciones intelectuales de Francia - iy de Europa! - a punto que nos hemos apropiado hasta los defectos. Sobre todo los defectos. ¿Es esto un bien? ¿Un mal? Es un hecho. Y ha de haber facilidad en la asimilación; pues suelen resultar intelectuales hispanoamericanos en quienes el "espíritu francés" es el propio. El poeta cubano Julián del Casal, tan estimado por Verlaine y Gustave Moreau, era más francés que Heredia y escribió en español ${ }^{25}$. Lo mismo el mexicano Gutiérrez Nájera ${ }^{26}$ y un brillante y aún poco notado joven argentino C. A. Becú ${ }^{27}$. Otro cubano, Augusto de Armas, fue a París, ya adolescente, publicó un libro de bellos versos franceses y murió de miseria; no sin que antes Banville reconociera en él una excepción de su frase a propósito de Wagner: "ningún extranjero hará nunca un verso francés que tenga sentido común" ${ }^{28}$. Y por lo que toca al esprit puro, ¿quién más francés, o mejor, más parisiense que nuestro general Mansilla? Rostand y Barres pueden atestiguarlo o Dujardin, que en uno de los últimos números de la Revue Blanche, le alaba por sus cualidades esencialmente parisienses ${ }^{29}$. Yo como escritor soy

${ }^{23}$ Se refiere a la parte del artículo de Valera en que este se asombra de la capacidad de Darío para asimilarse el espíritu francés, muy superior a la de los españoles más cosmopolitas o afrancesados, como José Marchena o Eugenio de Ochoa: "Yo no creo que se ha dado jamás caso parecido con ningún español peninsular. Todos tenemos un fondo de españolismo que nadie nos arranca ni a veinticinco tirones. En el famoso abate Marchena, con haber residido tanto tiempo en Francia, se ve lo español [...]. Ochoa era y siguió siendo siempre archi y ultraespañol, a pesar de su entusiasmo por las cosas de Francia" (en Darío 1995: 105-106). Palabras que Darío ya había citado en "Los colores del estandarte" y volverá a repetir en "El modernismo" (1899) de España contemporánea (1901).

${ }^{24}$ El escritor venezolano Pedro Emilio Coll se hizo cargo de la sección "Lettres latino-américaines" del Mercure de France entre 1897 y 1898 . En marzo de este último año publicó un panorama de la nueva producción modernista, en el que incluía Los raros y Prosas profanas, aunque, por cierto, sin darles excesiva relevancia y con pequeños reparos que Darío se encargaría de puntualizar poco después. De momento lo que interesa a éste es la contestación que Coll da a las críticas del español Leopoldo Alas "Clarín" sobre el afrancesamiento de Enrique Gómez Carrillo y otros latinoamericanos; una respuesta que recurre a las metáforas del alimento y la digestión, muy presentes en los discursos sobre dependencia/ independencia, imitación/ originalidad, inmadurez/ madurez cultural: "nous avons besoin de manger des idées, et que ne les ayant pas toujours trouvées en Espagne, nous sommes allés les chercher ailleurs. Aujourd'hui, l'assimilation d'éléments étrangers est pour nous une nécessité non seulement esthétique mais sociale. Quand notre organisme aura acquis des forces, nous saurons nous créer une physionomie et une vie propres" (Coll, 1898: 972).

${ }^{25}$ En los homenajes fúnebres que Darío dedicó a su amigo Julián del Casal puso especial cuidado en subrayar el excepcional reconocimiento que este alcanzó entre los más avanzados franceses. En la necrológica de 1894: "Cuando 'ese joven de mérito indiscutible' recibió una honrosa y fraternal carta de Huysmans, cuando Gustave Moreau reconoció su Salomé en los versos del cubano, cuando Verlaine le ha alabado deseando ardientemente su conversión, o más bien su vuelta al catolicismo, yo me he sentido orgulloso y satisfecho [...] Si Casal hubiese nacido en París..." (Darío 2012: 29). Y al año siguiente: "el poeta celebrado por Verlaine y alentado por Huysmans y Gustave Moreau" (38). Aquí lo presenta hiperbólicamente como "más francés" (acaso porque en ese momento lo consideraba "más moderno") que José-Maria de Heredia, el gran sonetista parnasiano francés de origen cubano.

${ }^{26}$ La referencia a Manuel Gutiérrez Nájera podría acompañarse de varias declaraciones similares. Ya en "Fotograbado” (1890) Darío incluyó a Gutiérrez Nájera entre el pequeño grupo de escritores hispanoamericanos animados por el "espíritu nuevo" del "modernismo". En 1896, tres años después de la muerte de Nájera, en el momento en que Justo Sierra presentó las poesías de este como una amalgama del "espíritu francés y la forma española", Darío lo caracterizó como "hermano" de Julián del Casal, "exquisito soñador" y "desterrado ciudadano de una Versalles ideal”: "fue uno de nuestros escasos parnasianos castellanos; sabía mucho de España y vivía su alma en Francia” (Darío 1953: 237). Poco después añadió: "Los poetas nuevos americanos de idioma castellano, hemos tenido que pasar rápidamente de la independencia mental de España y los antiguos españoles antes nuestros, a un Parnaso apenas iniciado y cuyo principal representante ha sido Gutiérrez Nájera; y luego a la corriente cerebral que hoy une en todo el mundo a señalados grupos que forman el culto y la vida de un arte cosmopolita y universal" (Darío 1938: 104).

${ }^{27}$ El joven Carlos Alfredo Becú, uno de los últimos modernistas en sumarse a la cofradía dariana de Buenos Aires, fue autor de una sola y rarísima plaquette de versos decadentes, En la plenitud de los éxtasis (1896), tras la que abandonó la literatura para dedicarse a la política y la diplomacia. Darío lo recordaría en su autobiografía (aunque equivocándole el nombre): "Un Benjamín de la tribu, Carlos Alberto (sic) Becú, publicó una plaquette, donde por primera vez aparecían en castellano versos libres a la manera francesa" $(1950: 1,128)$.

${ }^{28}$ En 1893 Darío dedicó una necrológica, más tarde incluida en Los raros, a Augusto de Armas, autor de Rimes byzantines (1891), en la que repite la misma anécdota de Banville (cfr. las anotaciones de Günther Schmigalle a Darío 2015: 95-107). Ya con más distancia y escepticismo sobre las posibilidades de que los escritores franceses reconociesen a los hispanoamericanos, volverá a mencionar el caso en "París y los escritores extranjeros" (1907), Letras, 1911 (Darío 1950: 1, 464).

${ }^{29}$ Durante su estancia en Buenos Aires Darío tuvo ocasión de tratar algo a Lucio V. Mansilla, notable personaje de la Argentina del 80 , militar, escritor y hombre de mundo, conocido popularmente por la admiración que su apostura y el brillo de su conversación levantaban en los salones de París. En 1903 Darío lo presentó a los lectores de la revista La Renaissance latine como un "parisien de Buenos-Ayres" (Darío 2017: 129). Cuando lo rencontró en París en 1910 escribió para La Nación: "Dos autoridades en la materia, Maurice Barrés y Robert de Montesquieu, han alabado como se debe el don de la palabra florida, oportuna y espiritual en este argentino, que es una de las personalidades más parisienses" (incluido como "En 
mentalmente francés, y a mucha honra. El espíritu francés triunfaría forzosamente en el mundo si ciertas estrecheces en algunos pensadores dirigentes no contuviesen la expansión. A destruir esto tiende notablemente M. Jean Finot, con el medio poderoso de su propaganda. ¿Por qué existiría el proverbio griego: “Ten al galo por amigo, no por vecino", que Quevedo citando a Eginharto, recuerda en su célebre carta al rey Luis XIII? ${ }^{30}$. El poeta Clovis Hughes, en la sesión de 24 de febrero de 1882, declaró en las Cámaras francesas: “¡Para la Francia no hay extranjeros!”. Era ello en verdad demasiado poético, dado el caso de lo que se trataba, y M. de Freycinet le contestó con cosas de la ley, en buen lenguaje político ${ }^{31}$. Pero en el dominio de ideas, el derecho que Vattel concede a los soberanos de prohibir la entrada a los extranjeros en su territorio, cuando lo tenga a bien, no debe existir ${ }^{32}$. Puesto que París es el punto central en donde todo irradia, toda belleza, todo pensamiento, toda obra, que llegue de cualquiera de los cuatro lados cardinales, tiene consagración y confirmación, puesto que París es la capital del Espíritu, el espíritu de París, el espíritu de Francia no debe encerrarse en arca de avaro. Todo hermano que pronuncie el schiboletu misterioso, debe de encontrar las puertas abiertas ${ }^{33}$. Eso desean, eso pregonan hoy inteligencias largas y generosas, y por lo tanto, genuinamente francesas. Cicerón grabó con su estilo: Usu vero urbis prohibere peregrinos sane inhumanum est (Offic. III) ${ }^{34}$.

La enquête en referencia da a entender que hay que esperar en una próxima evolución en ese sentido. El estudio de Finot que merece un estudio aparte, es hermoso, noble, y tiene el aplauso del pensamiento internacional.

Rubén Darío.

el Louvre", en Todo al vuelo, 1911; en Darío 1950: 2, 547). Efectivamente, como informa Sylvia Molloy, Mansilla "semble avoir connu d'ailleurs une certaine renommée dans les salons parisiens en tant que causeur raffiné. Proust parle de lui dans une lettre à Montesquiou, et Barrès préface un de ses livres, Estudios morales, et salue 'la vérité [...] la force vivante qu'il y a dans la philosophie de cet éminent causeur'. Ce livre est dédié 'au comte Robert de Montesquiou Fezensac, hommage d'amitié, de sympathie et d'admiration"' (1972: 19-20). Entre las amistades de Mansilla también estuvo Edmond Rostand, autor del citado Cyrano de Bergerac. En mi rastreo de La Revue Blanche no he podido, sin embargo, localizar hasta ahora la referencia a Mansilla de Édouard Dujardin que menciona Darío.

${ }^{30}$ En su citada Carta a Luis XIII, Quevedo recuerda efectivamente "el grito de aquel proverbio griego, que refiere Eginharto alemán, cronista de CarloMagno, que le sirvió en su vida, y dice así [...]: 'Ten al francés por amigo; no le tengas por vecino"” (1859: 261).

${ }^{31}$ Darío se refiere a la controversia que, con motivo de la expulsión de Francia del revolucionario ruso Piotr Lavrovitch Lavrov, enfrentó en la Cámara francesa al escritor y diputado socialista Clovis Hughes con el Presidente del Consejo de Ministros y encargado de Asuntos Extranjeros de la III República, Charles de Freycinet. Darío pudo conocer el caso por distintos medios, entre ellos el tratado de Emmanuel Bès de Berc De l'expulsion des étrangers (1888), donde se defiende el derecho de expulsión ejercido por los Estados para proteger la seguridad nacional: "Plus récemment encore, dans la séance du 24 février 1882, M. Clovis Hugues, dans un langage tout à fait théâtral, exprimait le même désir à la tribune, au sujet de l'expulsion de Lawroff: 'Lorsqu'on expulse de France un étranger, sous un Gouvernement démocratique, disait-il à la fin de son discours, lorsqu'on chasse un homme qui a cru à notre hospitalité, on touche à la liberté, on touche au principe même de la République. Du reste, nous sommes de ceux qui pensent que pour la France il n'y pas d'étrangers"' (Bès de Berc 1888: 12).

${ }^{32}$ El jurista suizo Emer de Vattel en El Derecho de Gentes (1775), una de las obras fundadoras del derecho internacional moderno, afirmó: "El soberano puede prohibir la entrada de su territorio, ya sea en general a todo extranjero, ya sea en ciertos casos o a ciertas personas, o en razón de algunos negocios en particular, según que lo halle por conveniente al bien del estado. Nada hay en esto que no emane de los derechos de dominio" (Vattel 1834: I, 345).

${ }^{33}$ Darío usa en varias ocasiones la palabra hebrea "shibboleth", que significa santo y seña, transcribiéndola como "schiboletu", "schiboleth" o "schibolet", y dándole el sentido de palabra sagrada o mágica, identificadora del talento y pasaporte para la gloria literaria. Hablando de él mismo como generoso descubridor y consagrador de jóvenes escritores dirá: "Cada vez que he oído el 'schiboleth' sagrado me he descubierto" (2011b: 167). En su cuento irónicamente autobiográfico "El último prólogo", el protagonista le reprocha: "usted no averigua si el neófito puede pronunciar como se debe el schibolet sagrado y lo deja entrar, no más, a la ciudad de la Fama..." (2005a: 281).

${ }^{34}$ Cicerón, De officiis, Libro III, 47: “Tambien es una injusticia prohibir a los extranjeros la estancia en nuestras ciudades” (Cicerón 1893: 171). Quede la cita como testimonio de los conocimientos que Darío tenía de los fundamentos básicos del derecho natural, pero también como prueba de que él no presumía en vano cuando en su autobiografía enumeró entre sus primerísimas lecturas Los Oficios del romano Cicerón, gran "rétor" y "orfebre" de la palabra: "En un viejo armario encontré los primeros libros que leyera. Eran un Quijote, las obras de Moratín, Las Mil y una noches, la Biblia, los Oficios de Cicerón, la Corina de Madame Stäel, un tomo de comedias clásicas españolas, y una novela terrorífica, de ya no recuerdo que autor, La Caverna de Strozzi. Extraña y ardua mezcla de cosas para la cabeza de un niño" (1950: I, 24). O cuando habló de las enseñanzas recibidas en la Compañía de Jesús: "Por lo menos conocíamos nuestros clásicos y cogíamos al pasar una que otra espiga de latín y aun de griego" (1950: 2, 626). 


\section{Referencias bibliográficas}

Arellano, Jorge Eduardo (1993), “Azul... y el proyecto cultural dariano”, en Azul. Nuevas Perspectivas, OEA: Interamer, pp. 99-113.

Bès de Berc, Emmanuel (1888). De l'expulsion des étrangers. Paris: Arthur Rousseau. Disponible en: https://gallica.bnf.fr

Blavatsky, Helena Petrovna (1924). Isis sin velo. Clave de los Misterios de la Ciencia y Teología Antigua y Moderna. Trad. de Federico Climent Terrer, 4 vols. Barcelona: Biblioteca Orientalista, $3^{\mathrm{a}}$ edición.

Carbonell, Marie (2004), "Les écrivains en leur miroir. Jeu et enjeux de l'enquête au sein de la République des Lettres", Mil neuf cent. Revue d'histoire intellectuelle, vol. 1, n 22 , pp. 29-58.

Caresani, Rodrigo Javier (ed.) (2013). Rubén Darío. Crónicas viajeras. Derroteros de una poética. Buenos Aires: UBA.

Casanova, Pascale (2001). La República mundial de las Letras. Barcelona: Anagrama.

Cicerón, Marco Tulio (1893). Los oficios, en Obras completas. Trad. de Manuel de Valbuena, Tomo IV. Madrid: Librería de la Viuda de Hernando.

Coll, Pedro Emilio (1898), "Lettres latino-américaines”, Mercure de France, Tome XXV, nº 99, mars 1898, pp. 968-973.

Colombi, Beatriz (2008). "Camino a la meca: escritores hispanoamericanos en París (1900-1920)", en Altamirano, Carlos (dir.), Historia de los intelectuales en América Latina, vol. I, Buenos Aires: Katz, pp. 544-566.

Contreras, Francisco (1930). Rubén Darío. Su vida y su obra. Barcelona: Agencia Mundial de Librerías.

Crépet, Eugène (dir.) (1887). Les poëtes français. Recueil des chefs-d'œuvre de la poésie française depuis les origines jusqu'à nos jours. Intr. par Sainte-Beuve, Tome I (Première période : du XIIe au XVIe siècle). Paris: Maison Quantin. Disponible en: https://gallica.bnf.fr

Darío, Rubén (1898), "Del amor de París y la influencia de la caña de azúcar, del café y de los cueros en el rastaquerismo", El Sol del Domingo, n ${ }^{\circ} 7,16$ octubre 1898, p. 1.

Darío, Rubén (1919), "La fiesta de Francia", en Obras completas, vol. 20 (Prosa dispersa). Madrid: Mundo Latino, pp. $123-132$.

Darío, Rubén (1938). Escritos inéditos de Rubén Darío. Ed. Erwin K. Mapes. Nueva York: Instituto de las Españas.

Darío, Rubén (1950). Obras completas, 5 vols. Madrid: Afrodisio Aguado.

Darío, Rubén (1953), "Galería de Modernos. Gutiérrez Nájera" (1896), en Eduardo Héctor Duffau, "Nuevos encuentros con Rubén Darío. 10 rimas y 6 prosas desconocidas", Ábside: revista de cultura mexicana, vol. 17, $\mathrm{n}^{\circ} 2$, abril-junio 1953, pp. 211-238.

Darío, Rubén (1967). Poesías completas. Ed. A. Méndez Plancarte y A. Oliver Belmás. Madrid: Aguilar.

Darío, Rubén (1995). Azul... Cantos de vida y esperanza. Ed. José María Martínez. Madrid: Cátedra.

Darío, Rubén (2001). La caravana pasa. Libro tercero. Ed. Günther Schmigalle. Berlin: tranvía-Verlag Water Frey.

Darío, Rubén (2004). La caravana pasa. Libro cuarto y quinto y último. Ed. Günther Schmigalle. Berlin: tranvía-Verlag Water Frey.

Darío, Rubén (2005a). Cuentos completos. Ed. Jorge Eduardo Arellano. Managua: anama.

Darío, Rubén (2005b). La caravana pasa. Libro segundo. Ed. Günther Schmigalle. Berlin: tranvía-Verlag Water Frey.

Darío, Rubén (2008). ¿Va arder París...? Crónicas cosmopolitas, 1892-1912. Ed. Günther Schmigalle. Madrid: Veintisiete Letras.

Darío, Rubén (2011a). La República de Panamá y otras crónicas desconocidas. Ed. Jorge Eduardo Arellano. Managua: Academia Nicaragüense de la Lengua.

Darío, Rubén (2011b). Crónicas desconocidas, 1906-1914. Ed. Günther Schmigalle. Managua: Academia Nicaragüense de la Lengua.

Darío, Rubén (2012), "Julián del Casal" (La Habana Elegante, 1894) y "El General Lachambre. Recuerdo de La Habana" (La Nación, 1895), en Francisco Morán (ed.). La Habana Elegante. Segunda época. XV Aniversario (1998-2012). Julián del Casal (In. Memoriam). Miami: Stockcero, pp. 29-31 y 38-39.

Darío, Rubén (2017), "Le Mouvement latin. Amérique Latine" (La Renaissance latine, 1903), en Günther Schmigalle, "Un artículo desconocido de Rubén Darío sobre el movimiento latino en América", Istmo. Revista virtual de estudios literarios y culturales centroamericanos, $\mathrm{n}^{\circ} 35$, pp. 92-131.

"El espíritu francés" (1898), La Nación, Buenos Aires, 29 julio de 1898, pp. 2-3.

"Enquête sur l'esprit français" (1898), Revue des Revues, vol. XXVI, 1 julio de 1898, pp. 1-41. Disponible en: https://gallica.bnf.fr

Farinelli, Arturo (1896), "Notas críticas. Baltasar Gracián und die Hoflitterature in Deutschland, por K. Borinski. Halle a. S. Max Niemeyer, 1894", Revista Crítica de Historia y literatura españolas, portuguesas e hispano-americanas, Madrid, enero 1896, pp. 33-55.

Finot, Jean (1898), "La formation, le présent et l'avenir de l'esprit français", Revue des Revues, vol. XXVI, 1 julio de 1898 , pp. 42-59.

Disponible en: https://gallica.bnf.fr

García Morales, Alfonso (2004), "Un lugar para el arte. Rubén Darío y Eduardo Schiaffino (Documentos y cartas inéditas)", Anales de literatura hispanoamericana, Universidad Complutense de Madrid, vol. 33, 2004, pp. 103-173. 
García Morales, Alfonso (2006), "Un artículo desconocido de Rubén Darío: "Mallarmé. Notas para un ensayo futuro"”, Anales de literatura hispanoamericana, Universidad Complutense de Madrid, vol. 35, 2006, pp. 31-54.

Gourmont, Remy (1903), «Les Races latines» (junio 1898), en Épilogues. Réflexions sur la vie. 1895-1898. Paris: Mercure de France, 2e édition, pp. 253-256.

Disponible en: https://gallica.bnf.fr

Ligne, Charles Joseph, Prince de (1828), “De l'armée française pendant la Révolution”, en Mémoires et mélanges historiques et littéraires. Paris: Ammbroise Dupont, Vol. 4, pp. 137-145.

Lvovich, Daniel (2003), "No es este un asunto de Francia sino un asunto de la humanidad. Notas sobre la recepción del Caso Dreyfus en Buenos Aires”, Anuario IEHS, vol. 18, 2003, pp. 273-302.

Molloy, Sylvia (1972), La diffusion de la littérature hispano-américaine en France au XXe siècle. Paris: Presses Universitaires de France.

Montedite (2913). Édition critique des Pensées de Montesquieu. Ed. Carole Dornier. Caen: Presses universitaires de Caen. Disponible en: http://www.unicaen.fr/services/puc/sources/Montesquieu

Moser, Gerald y Hensley C. Woodbridge (1964). Rubén Darío y El Cojo Ilustrado. New York: Hispanic Institute/ Columbia University.

Noguerol, Francisca (1998). "De parisitis y rastacuerismo: Rubén Darío en Francia”, en García Morales, Alfonso (ed.), Rubén Darío. Estudios en el Centenario de Los raros y Prosas profanas. Sevilla: Universidad de Sevilla, pp. 165188.

Paz, Octavio (1994). Obras completas, 14 vols. México: Círculo de Lectores/ FCE.

Pera, Cristóbal (1997). Modernistas en París. El mito de París en la prosa modernista hispanoamericana. Bern: Peter Lang.

Quevedo y Villegas, Francisco (1859). Discursos políticos, en Obras, Tomo I. Ed. Aureliano Fernández-Guerra y Orbe. Madrid: M. Rivadeneyra/Biblioteca de Autores Españoles desde la formación del lenguaje hasta nuestros días, volumen 27.

Disponible en: http://www.cervantesvirtual.com

Rama, Ángel (1973), "Sueños, espíritus, ideología y arte del diálogo modernista con Europa”, en Rubén Darío. El mundo de los sueños. Barcelona: Universidad de Puerto Rico, pp. 5-61.

Renan, Ernest (1882). Qu'est-ce qu'une nation? Paris: Calmann Lévy fréres. Disponible en http://ernest-renan.fr/les-oeuvres-de-renan

Renan, Ernest (1892), “Conférence faite a l'Alliance pour la propagation de la langue française le 2 février 1888”, en Feuilles détachées. Paris: Calmann Lévy fréres, pp. 255-270.

Sainte-Beuve, Charles-Augustin (1867 y 1870). Causeries du lundi, Vols. 8 y 13, 3e éd. Paris: Garnier frères. Disponible en: https://gallica.bnf.fr

Salinas, Pedro (1975). La poesía de Rubén Darío. Ensayo sobre el tema y los temas del poeta. Barcelona: Seix Barral.

Séneca, Lucio Anneo (1884). Tratados filosóficos. Trad. de Francisco Navarro y Calvo. Madrid: Luis Navarro y Calvo. Disponible en: http://www.cervantesvirtual.com

Schmigalle, Günther (2010), “La Caravana pasa de Rubén Darío: epítome del periodismo modernista”, en Jeffrey Browitt y Werner Mackenbach: Rubén Darío: cosmopolita arraigado. Managua: IHNCA/UCA, pp. 41-53.

Schmigalle, Günther (2011-2012), "Rubén Darío y el asunto Dreyfus. Una crónica desconocida y su contexto", Repertorio dariano 2011-2012, Managua, pp. 157-185.

Schmigalle, Günther (2014), "Problemas textuales en la edición de los cuentos de Rubén Darío: El caso de la señorita Amelia", Anales de Literatura Hispanoamericana, 2014, vol. 43, pp. 191-207.

Siskind, Mariano (2016). Deseos cosmopolitas. Modernidad global y literatura mundial en América Latina. Buenos Aires: FCE.

Stendhal (1929). Vie de Rossini, vol. 2. Ed. Henri Martineau. Paris: Le Divan. Disponible en https://gallica.bnf.fr

Vattel, Emer de (1834). El Derecho de Gentes. Trad. de Manuel María Pascual. Madrid: Imprenta de León Amarita. 